\title{
Batch injection analysis in tandem with electrochemical detection: the recent trends and an overview of the latest applications (2015-2020)
}

\author{
Marek Haššo ${ }^{1}$ Lubomír Švorc ${ }^{1}[0$
}

Received: 27 December 2021 / Accepted: 3 February 2022 / Published online: 23 February 2022

(c) Springer-Verlag GmbH Austria, part of Springer Nature 2022

\begin{abstract}
The purpose of the proposed review is to refer the contemporary capability of automated analytical systems, in particular batch injection analysis (BIA) in connection with electrochemical detection, for widespread applications in analytical chemistry. This combination recently represents an efficient tool for improvement of method parameters, such as speed, selectivity, and sampling rate for sensing of miscellaneous organic and inorganic substances. The review is focused on conception and usage of BIA in tandem with electrochemical detection utilizing various techniques, namely amperometry, voltammetry, and multiple pulse amperometry, as well as design of electrochemical cells constructed for BIA systems is discussed. Finally, this paper also summarizes the comprehensive overview of works published from 2015 to 2020 dealing with the electrochemical determination of different analytes by BIA in various matrices.
\end{abstract}

\section{Graphical abstract}

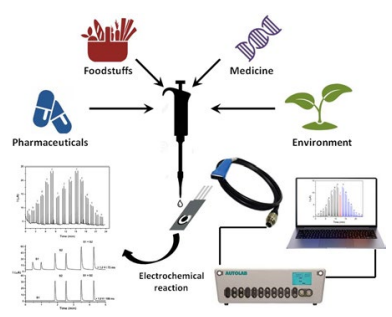

Keywords Batch injection analysis · Amperometry $\cdot$ Electrochemistry $\cdot$ Voltammetry $\cdot$ Automated analytical system

\section{Introduction}

Achieving the correct result of the analysis and the capability of analyzing as many real samples as possible in the shortest analyzed time plays an important role in various fields of analytical practice, including food or drugs quality control, environmental pollution, and even the early diagnosis of the diseases. From these reasons, the enlargement of automated analytical systems has been supported and

Lubomír Švorc

lubomir.svorc@stuba.sk

Institute of Analytical Chemistry, Faculty of Chemical and Food Technology, Slovak University of Technology in Bratislava, 81237 Bratislava, Slovak Republic stimulated taking into account also objective of increasing demands on the development of analytical methods. In this respect, sensitivity, selectivity, speed, and last but not least automation and the financial aspects of the analysis are essential parameters. The first automated analytical system was flow injection analysis (FIA), introduced by Ružička and Hansen in 1975. Wide spectrum of compounds in fields of pharmaceutical (drugs), food (phthalates, antioxidants, and sweeteners), and environmental (plant macronutrient and micronutrient, surfactants, heavy metals) analysis was investigated by FIA [1-5]. Although FIA provides many advantages, for instance, speed, high analytical frequency, precise, and reproducible results, it has also some drawbacks connected with consumption of reagent/carrier solution and 
utilization of pumps and valves. These disadvantages have been eliminated by an establishment of another automated analytical system called batch injection analysis (BIA), which was developed by Wang and Taha in 1991 [6]. The principle of BIA lies in an injection of a small volume of sample using a micropipette directly against a nearby detector that is immersed in a large-volume blank solution. Many types of detectors, such as fluorometer, calorimeter, and spectrophotometer, also voltammetric and potentiometric detection, can be combined with BIA to achieve a wide spectrum of determinable substances [7-12].

Generally, it should be mentioned that the greatest disadvantage of electroanalytical methods is oftentimes insufficient selectivity, mainly due to the close peak potentials of two or more electroactive substances in analyzed solution. The most frequently used electrochemical detector in BIA system is the amperometric detector. This connection appears to be an excellent way to partially eliminate the selectivity problem, without the need of complicated sample treatment step, usually using simple correction factor. This represents an important stage in development of electroanalytical methods, also due to the fact that the lower selectivity has been oftentimes solved using a chromatographic separation (e.g., high-performance liquid chromatography) or different types of extraction methods in sample pretreatment step prior to analysis [13-16]. In fact, electroanalytical methods have many advantages, such as large dynamic concentration range of electroanalytical response, low limit of detection, low cost, fast response time, size of measuring device, and also possibility of miniaturization and usage as a portable device in the so-called in situ measurements. Besides, a miniaturization of advanced electronics has led to fabrication of screen-printed electrodes based on various materials, which in connection with automated analytical systems (e.g., BIA and/or FIA) will move the level of automation and field of application to the higher level [17-19].

Based on this fact, the presented review aims to inform the reader about the current position and trends of BIA in tandem with electrochemical detection in the determination of inorganic and organic compounds. At the same time, the comprehensive overview of electroanalytical applications of the BIA system in various matrices is summarized within the period from 2015 to 2020.

\section{Automated systems in analytical chemistry}

The need to analyze a large number of samples with good precision, high speed, and good repeatability gave rise to the development of automated analytical systems. Currently, FIA is the most used automated analytical system consisting in injecting the sample into a continuously flowing carrier stream. In FIA, a small volume of analyzed sample is applied by injection device directly into a carrier medium flowing through a tube (Fig. 1). The sample zone is dispersed slowly into the carrier stream due to convection and axial and radial diffusion when moving laminar throughout the conduit. Detectable species are produced by reagents that are mixed with the sample zone by the influence of radial dispersion. The height or area of recorded analytical signal can be used to determine the amount of analyte by calibration curve or standard addition method. The entire process of analysis, including sample injection, transport, addition of reagent/ reagents, reaction, and detection, is realized quickly at high degree of precision [1].

Another generation of automated analytical systems is sequential injection analysis (SIA). SIA is composed of only a syringe type single reversible pump, holding coil, reaction coil, multifunction selection valve, and detector. This system enables accurate sequence of sample and reagent addition and their mixing before switching the valve and then the reaction product is transported to the detection section. The main advantage of SIA in comparison with FIA is that only a one pump, that can be secluded from possibly damaging reagents by deionized water, is needed [20].

Generally, automated analytical systems, such as FIA, SIA, and lab-on-valve, are based on the following:

1. Injection of sample or reagents

2. Controlled dispersion of the injected zone

3. Reproducible timing of processes in the flowing stream

In 1991, another innovative approach to automated analytical systems was developed by Wang and Taha, namely BIA. This system represents an alternative way to perform rapid measurements. It is a relatively young analytical technique which in connection with electrochemical detection is more widely applied in the last six years as evidenced by the graph of the number of publications according to the results from Web of Science database (Fig. 2). Herein, it should be emphasized that the use of the FIA systems absolutely dominates in the scientific literature. Several reviews $[4,5,9,19$, 21-23] and numerous scientific publications (books, book

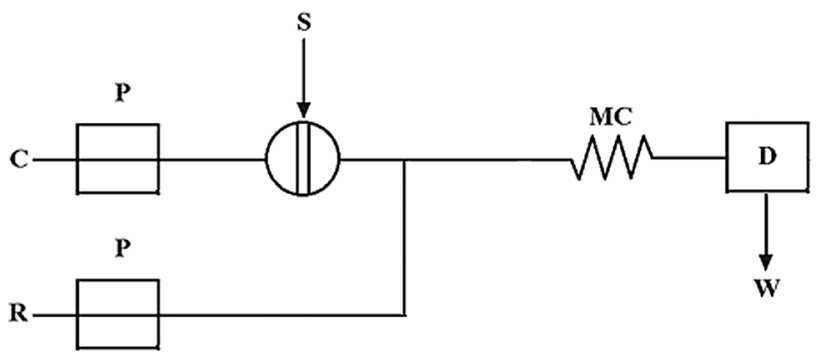

Fig. 1 Components of FIA system [1]: $P$ pump, $C$ carrier stream of liquid, $R$ reagent, $S$ injection port, $M C$ mixing cell, $D$ detector, $W$ waste 


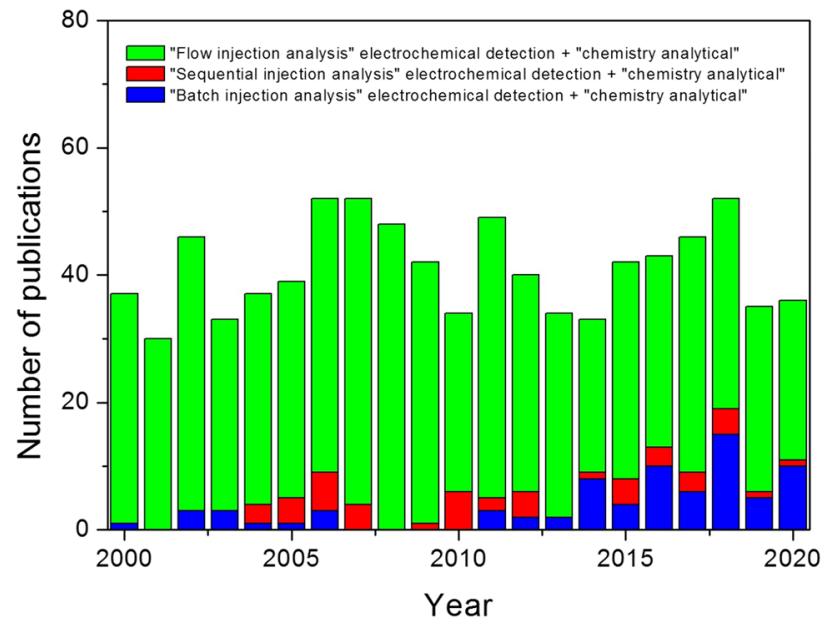

Fig. 2 Number of publications derived from WoS database issued from 2000 to 2020 regarding: 1. FIA (keywords: "flow injection analysis" electrochemical detection + category- "chemistry analytical" 923 articles, 85 review articles); 2. SIA (keywords: "sequential injection analysis" electrochemical detection + category- "chemistry analytical" 40 articles, 10 review articles); and 3. BIA (keywords: "batch injection analysis" electrochemical detection + category- "chemistry analytical" 78 articles, 7 review articles)

chapters, articles [24-26]), focused on automated injection systems, including FIA, SIA, and BIA, have been published in last twenty years. The most of these publications devoted to instrumentation and using automated analytical systems as rapid, sensitive, and portable devices to determine various organic compounds in medical, biological, food, and environmental types of sample.

\section{Batch injection analysis}

The first BIA system used amperometric detection and its concept can be explained by using a system shown in Fig. 3 [6]. Electrochemical cell was made of plexiglass. The working electrode (A) was inserted into the cell through a pre-drilled hole from below. The tip of the pipette (D) was placed through the hole directly opposite to the center of the working electrode. The pipette was hold by a clamp, that ensuring a reproducible and quick positioning after each filling. In two other holes the reference (C) and auxiliary electrode (B) were accommodated. The hole (E) was used to bring the blank solution (a supporting electrolyte). In the electrochemical cell were also a drain point $(G)$ and a stirrer (F). Injected sample forms a zone that disperses on way to the detection system with reproducible transport and the result is a peak-shaped response of detection system. Recorded response is followed by a rapid fall of the signal to the baseline due to the washing out effect of the wall-jet configuration (Fig. 4) [27].

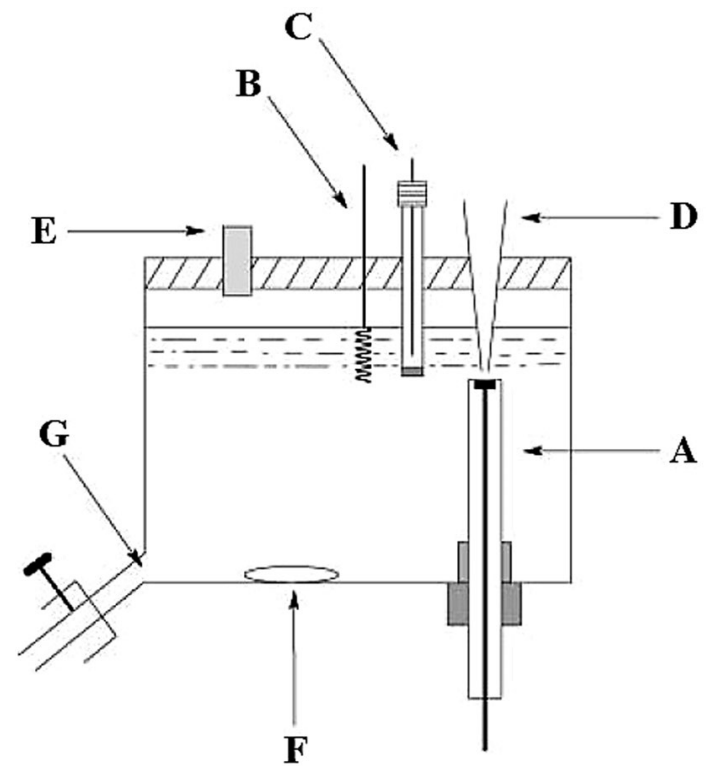

Fig. 3 Scheme of BIA cell: $A$ working electrode; $B$ counter electrode; $C$ reference electrode; $D$ micropipette tip; $E$ hole; $F$ stirring bar; $G$ drainage [6]

The wall-jet electrode is a hydrodynamic electrode in which the flow is caused by a jet of liquid that impacts a planar electrode surface at right angles and spreads out radially over that surface while the fluid outside the jet being at rest. Only fresh solution from injection can reach the electrode surface because the wall in which the electrode is inserted is very inconsistent accessible. It represents a crucial factor for the application of wall-jet disk electrodes. The response of detector is not influenced by the size of electrochemical cell,

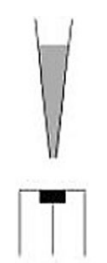

A

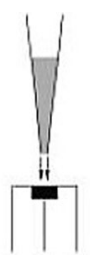

B

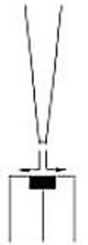

C

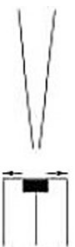

D

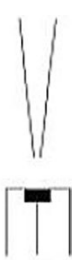

$\mathbf{E}$

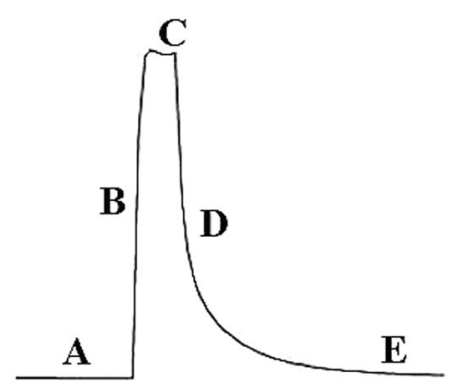

Fig. 4 Steps in BIA operation: $A$ before injection, $B$ transport during the injection, $C$ end of the injection, $D$ washing out, $E$ final equilibrium [27] 
but the important parameters being the injected volume and volume flow rate of the jet of incoming solution. The maximum response that can be obtained at the wall-jet electrode is the diffusion limited current.

At the beginning, the success of BIA was highly dependent on the operator because the injections were done with a manual operated micropipette. This problem was solved by computerized pipettes with programmable dispersion which turns this operation as very suitable, even for untrained users. Highly reproducible piston movement of computercontrolled pipettes made it possible to obtain precise and accurate results of the analysis [28].

Generally, there is a demand to provide analytical data rapidly, and as close to real time as possible. In this sense, BIA yields many attractive features similar to FIA system, like speed, sample size, sensitivity, and reproducibility. BIA resembles the FIA in that an injected an aliquot of analyte is reproducible transported to a stationary detector and during this process a small volume of sample is rapidly dispersed and greatly diluted over the entire volume in electrochemical cell. BIA, in opposite to FIA, eliminates some problems related to flow systems, e.g., use of pump or valves, expense of disposal of reagent, and carrier solution [6].

The success of BIA consists in a combination of two factors: (i) the hydrodynamic principle of electrochemical cell ("wall-jet" arrangement) and (ii) the enormous dilution of the microliter samples in the entire volume of the cell. At the beginning, the volume of first electrochemical cells developed for BIA was very large; thus, corroborating the large dilution of the microliter samples, and during the analysis, it was necessary to stir the solution in the cell. BIA in amperometric mode was also successfully realized in small cells in which memory effects, due to the build-up of the analyte, were not noticed [29].

The small-cell design preserves the attractive features of large-volume BIA cells, like simplicity, precision, speed, and small consumption of sample. It was also observed that stirring the solution does not affect the intensity of peak current. Without stirring the solution, a very fast decrease in the current can be recorded for small cells. Based on the above-mentioned advantages, the BIA can be used as portable analytical kits.

\section{Type and design of electrochemical cells in BIA}

Currently, there are several commercially available electrochemical cells with different shapes, dimensions, and constructed materials that can be used for electrochemical analysis. Alternatively, the cells can be manufactured in laboratory using subtractive manufacturing techniques as $3 \mathrm{D}$ printing. This represents an important collaboration of different scientific areas, like Analytical Chemistry, Electrochemistry, and Material Chemistry. 3D printing is a technique for producing 3D objects by computer-controlled layer-by-layer modeling as far as a final structure of object is created [30]. There are many types of 3D printing technologies; however, the simplest, cheapest and most popular technology is fused deposition modeling (FDM). In this technique a thermoplastic material, e.g., polylactic acid (PLA) is heated to semi-molten state and then is extruding by dispenser nozzle head on the support material (Fig. 5). The deposited material solidifies and forms a layer which stacks on top of the layer created in previous step. This step is repeated layer by layer until the object is compiled. These 3D printing BIA cells have been successfully used in many analytical applications [31-34]. The construction of the BIA cell may be the major barrier for many scientific groups to utilize this technique in analytical measurements. On the other hand, it could be decreased by growing commercial availability of BIA cells or also by an implementation of 3D printers to laboratories which will allow scientists to print 3D BIA cells with precisely defined dimensions.

From the viewpoint of the construction of BIA cells it is very important that the wall opposite the detector in the cell is sufficiently distant and the tip of the micropipette is a few millimeters away from the surface of the detector. Achieving these two requirements results in the elimination of interference associated with solution recirculation in the BIA cell. At present, the volume of electrolyte in BIA cell is around $40 \mathrm{~cm}^{3}$, which allows easy portability of the BIA system for in situ measurements. Additionally, in connection with the smaller injection volume of the sample $\left(50-100 \mathrm{~mm}^{3}\right)$ compared to the volume of used electrolyte in BIA cell, it is possible to perform analyses without the need to remove solution, because no memory effects are observed. Programmable electronic micropipettes have various capabilities, such as different injection speed and injected volume, as well as the ability to create a procedure in which the same or different volumes of analyzed solution are injected in successive injections in a precise time period. The use of these computer-controlled procedures leads to excellent values of accuracy and repeatability and also allows automation of analysis and avoidance of possible personal mistakes on the part of the lab worker [35].

\section{Electrochemical technique used in BIA}

Several electrochemical techniques can be combined with BIA, but amperometry or multiple pulse amperometry (MPA) are the most frequently used. The combination of BIA with MPA represents an excellent way to partially eliminate problem with insufficient selectivity of electroanalytical methods, mainly in case if the analyzed sample is too complicated and contains many electroactive species, in which oxidation or reduction peaks are too close. Appropriate choice of detection potentials of analyzed 


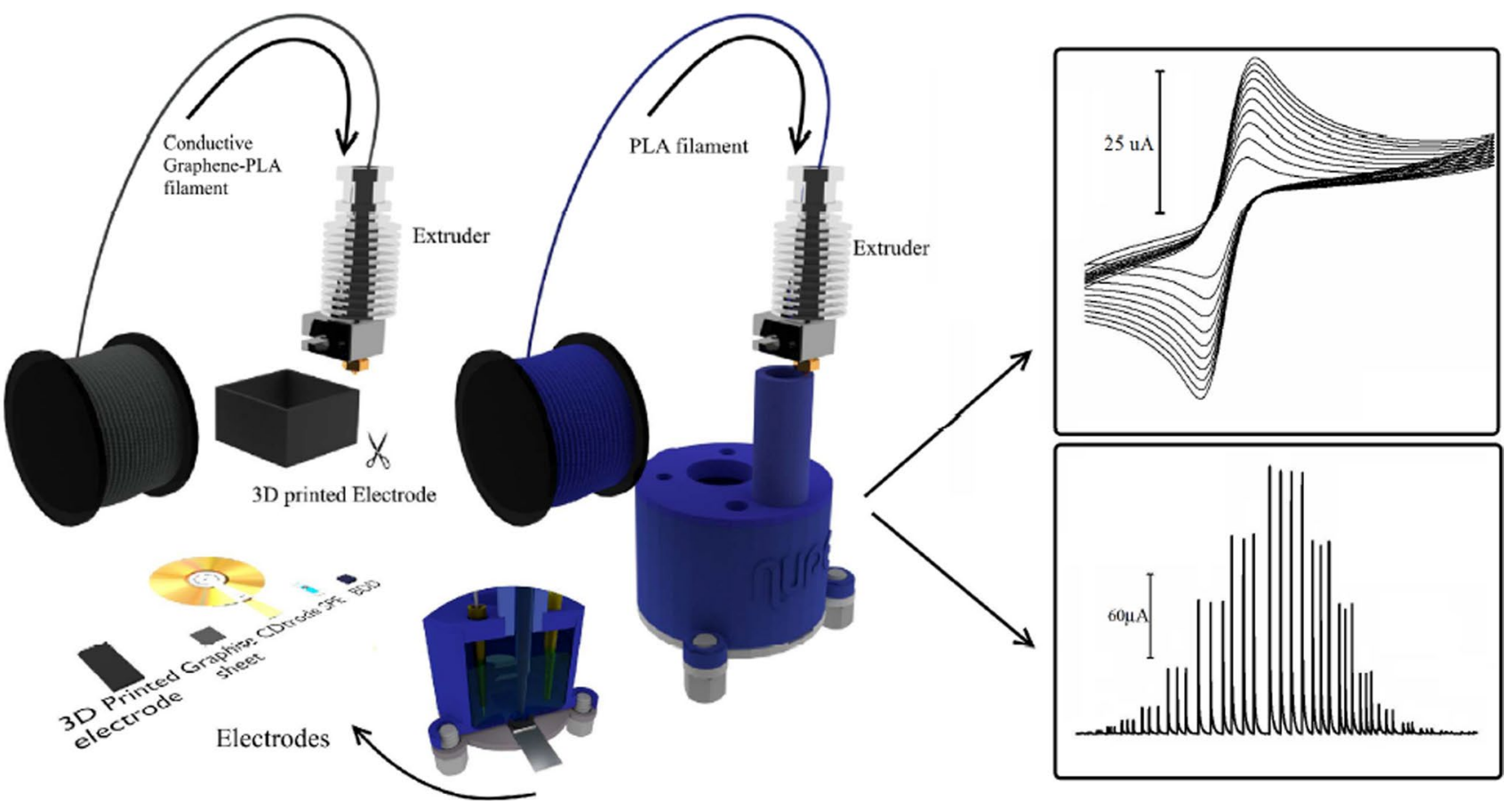

Fig. 5 Scheme of manufacturing of 3D printing electrodes and BIA cells [31]

species in MPA enables to selectively oxidize or reduce these electroactive substances, which opens up the possibility of simultaneous determination of compounds in a mixture without the need of chromatographic separation or any other extraction techniques. In addition to amperometry, it is possible to perform potentiometry or voltammetric techniques, such as cyclic voltammetry, square-wave voltammetry, and differential pulse voltammetry. A specific type of measurement is construction of the so-called "point-by-point pseudo-steady-state" voltammetric curve by successive injection at slow scan rate (Fig. 6) [36].

The use of pulse voltammetric technique, such as squarewave voltammetry (SWV) or differential pulse voltammetry (DPV), enables to eliminate capacitive current, which results in lower limit of detection (LOD) of developed methods. One of the favorable ways to increase sensitivity of developing analytical methods is the application of preconcentration techniques, in which the analyte is accumulated over a period of time, sometimes called deposition time on the (a)

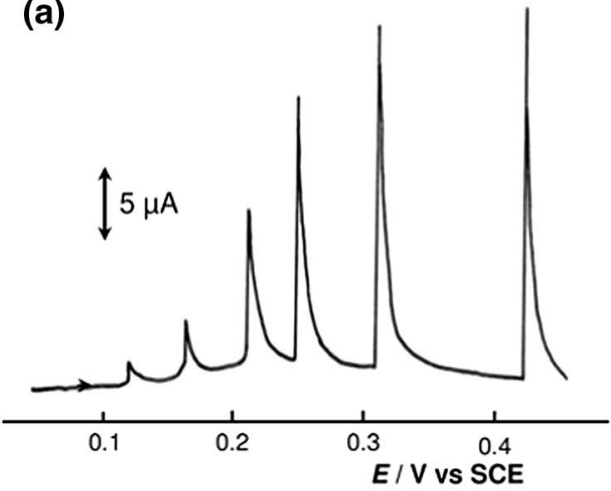

(b)

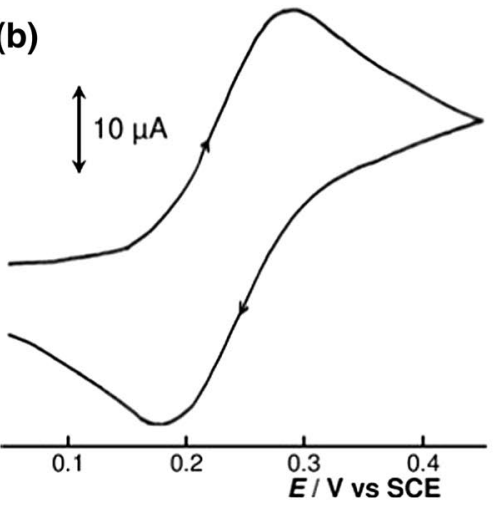

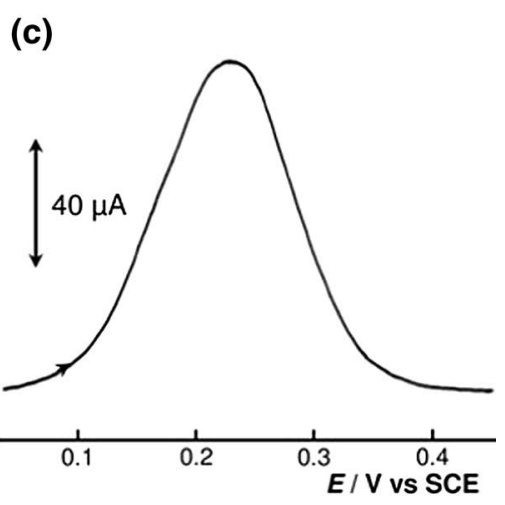

Fig. 6 Current responses for electrochemical oxidation of $2 \times 10^{-3} \mathrm{~mol} \mathrm{dm}^{-3} \mathrm{~K}_{4}\left[\mathrm{Fe}(\mathrm{CN})_{6}\right]$ in $0.4 \mathrm{~mol} \mathrm{dm}^{-3} \mathrm{~K}_{2} \mathrm{SO}_{4}$ at a Pt electrode; injection flow rate of $24.5 \mathrm{~mm}^{3} \mathrm{~s}^{-1}$. a Point-by-point pseudosteady-state voltammetric curve after consecutive injections of
$16 \mathrm{~mm}^{3}$ during a potential sweep at scan rate $10 \mathrm{mV} \mathrm{s}^{-1}$; b cyclic voltammogram recorded after injection of $100 \mathrm{~mm}^{3}$ at scan rate $100 \mathrm{mV} \mathrm{s}^{-1}$; c square-wave voltammogram recorded during injection of $100 \mathrm{~mm}^{3}$ at frequency of $100 \mathrm{~Hz}$ and amplitude of $50 \mathrm{mV}$ [36] 
surface of the electrode. It is important to realize that the efficiency of the accumulation during deposition of analyte on the electrode by electrolysis is highest at the lowest flow rate. The main reason is the fact that the injection of analyte will not be forced radially out of the way from the electrode, and will be able to diffuse back to the detector surface [37].

\section{Electroanalytical applications of BIA}

BIA technique may be used for determination of various types of analytes in different matrices, e.g., environmental, pharmaceutical, and food samples. Especially, analysis of water samples (drinking, river, waste, surface, underground, or industrial) and monitoring of the essential parameters, such as trace concentrations of heavy metal ions $\mathrm{Cu}^{2+}$, $\mathrm{Pb}^{2+}, \mathrm{Cd}^{2+}, \mathrm{Zn}^{2+}, \mathrm{Ni}^{2+}, \mathrm{Co}^{2+}$, and $\mathrm{Cr}^{6+}$ ) [38-41] or other ions $\left(\mathrm{NH}_{4}^{+}, \mathrm{Na}^{+}, \mathrm{K}^{+}, \mathrm{Mg}^{2+}\right.$, and $\left.\mathrm{Ca}^{2+}\right)$ [42]. Concerning the pharmaceutical samples, it is mainly a matter of determining the active substance content (including the determination of their excipients) and also simultaneous determination of more than one drug in a sample [43]. BIA was also used in detecting DNA damage caused by UV radiation [44].

In comparison to FIA, interferences and fouling of the electrode are reduced by BIA due to the small contact time between the sample and the electrode. The connection of BIA with ion-selective electrode (ISE) was successfully applied in determination of ions in mineral water, but the usage of this connection is highly limited to non-availability of selective sensors. The applications of spectral methods in connection with BIA are still uncharted, in spite of the large possibilities of applications, such as employing optical fibers [27]. The comprehensive overview of the basic characteristics and parameters of determination of analytes (published in the period of 2015-2020) by BIA with voltammetric or amperometric detection is clearly given in Table 1. As an electrode material, a boron-doped diamond (BDD) has been used in most cases, which may be related to its unique properties, such as mechanical and chemical stability, wide potential window, low background current, and resistance to passivation of organic substances or their redox products [45-48].

\section{Analysis of foodstuffs}

Determination of organic substances in foodstuffs with BIA has been object of only few studies in years 2015-2020 [49-54]. Analyzed samples were mostly dietary supplements, such as green tea, "spiked" mineral water, beverages (beer, coke, energy drink, vodka, and whisky), and milk. A common feature for monitored molecules in these samples has been the fact that all have been oxidized and determined using direct amperometry, MPA, or SWV. Besides, in all cases, simple pretreatment step (filtration or dilution in supporting electrolyte) was required before the analysis. These simply pretreated samples were directly injected by automated micropipette to electrochemical cell and the amount of respective analytes was determined by the method of calibration curve or by the standard addition method. In order to improve sensitivity and selectivity of determination, modification of working electrode was performed by modifier [49, 54].

During BIA experiments, the researchers had also following problem. When direct amperometry was used as detection technique, it led to fouling of unmodified "bare" glassy carbon electrode, which was related to decrease of a recorded amperometric signal. To avoid this negative aspect, MPA instead of direct amperometry was utilized as a detection technique and it resulted in a significantly improvement of stability of recorded signal. The reason for this greater stability of signal consisted in using cleaning potential for short period time, by which electroactive surface was constantly renewed. This phenomenon has been observed in other similar work [50].

As a demonstrative example of BIA determination of organic molecules in foodstuffs we could introduce the work of Oliveira et al., who developed electrochemical portable method for on-site screening of scopolamine in beverages. The various samples of beverages, including vodka, whisky, coke, and energy drink, were analyzed by the proposed method. The fast screening has been possible after simple sample pretreatment (dilution in supporting electrolyte), which predestined this system to a testing and also for analysis in laboratories where sophisticated laboratory equipment was not available. SWV was used as detection technique. In addition, the proposed system needed only an aliquot of sample injected per analysis and also allowed more than two hundred screenings without need of solution replenishment [52].

\section{Analysis of pharmaceutical samples}

A plenty of the articles published in years from 2015 to 2020 has focused on the determination of organic substances using BIA in pharmaceutical samples involving tablets, capsules, injectable solutions, and oral solutions [32, 54-82]. In most work, the pharmaceutical samples used for analysis were tablets or capsules. All real samples, including injectable solution, oral solutions, tablets, or eye drop, were simply pretreated by dilution in a supporting electrolyte, but in some cases it was necessary to use sonification of sample to improve solubility of substances before the analysis. Owing to the fact that samples with simple matrix were analyzed, the amount of corresponding substances was determined directly from calibration curve. Although electroanalytical methods are generally considered to be less selective, there is a substantial number of papers in which the BIA in 
Table 1 Overview of basic characteristics and parameters of voltammetric and amperometric determination of selected analytes using BIA (published in 2015-2020, alphabetically ordered according to analyte)

\begin{tabular}{|c|c|c|c|c|c|c|c|}
\hline Analyte & $\begin{array}{l}\text { Supporting elec- } \\
\text { trolyte }\end{array}$ & Working electrode & $\begin{array}{l}\text { Detection } \\
\text { potential/V }\end{array}$ & Technique & $\mathrm{LOD} / 10^{-6} \mathrm{~g} \mathrm{dm}^{-3}$ & Analyzed sample & References \\
\hline$\alpha$-Amylase & $\begin{array}{l}0.1 \mathrm{~mol} \mathrm{dm}^{-3} \\
\mathrm{NaOH}\end{array}$ & $\mathrm{CuO}-\mathrm{CuE}$ & +0.60 & Amperometry & $\begin{array}{l}50.0 \times 10^{-6} * \mathrm{~mol} \\
\mathrm{dm}^{-3}\end{array}$ & Biological (saliva) & [83] \\
\hline$\alpha$-Lipoic acid & PBS pH 7.0 & CoPc-PGE & +0.90 & Amperometry & 3.1 & $\begin{array}{l}\text { Food (supplement) } \\
\text { biological (urine) }\end{array}$ & [49] \\
\hline $\begin{array}{l}\text { 2,2-Diphenyl- } \\
\text { 1-picrylhydrazyl }\end{array}$ & $\begin{array}{l}\text { ABS pH } 5.5 \text { with } \\
\text { ethanol }(40 / 60 \text {, } \\
v / v)\end{array}$ & GCE & +0.05 & Amperometry & 394.3 & $\begin{array}{l}\text { Environmental } \\
\text { (plant extract) }\end{array}$ & [89] \\
\hline $\begin{array}{l}\text { 2,6-Di-tert-butyl- } \\
\text { phenol }\end{array}$ & $\begin{array}{l}0.1 \mathrm{~mol} \mathrm{dm}^{-3} \\
\mathrm{HClO}_{4} \text { with } \\
99 \% \text { ethanol } \\
(v / v)\end{array}$ & SPGE & +1.10 & Amperometry & 290.0 & Jet fuel & [97] \\
\hline 4-Chloroaniline & $\begin{array}{l}0.03 \mathrm{~mol} \mathrm{dm}^{-3} \\
\text { acetic acid }\end{array}$ & MWCNTs-GCE & +1.00 & Amperometry & 6.4 & $\begin{array}{l}\text { Pharmaceutical } \\
\text { (skin disinfectant) }\end{array}$ & {$[55]$} \\
\hline \multirow[t]{2}{*}{$\begin{array}{l}\text { 8-Chlorotheophyl- } \\
\text { line }\end{array}$} & $\begin{array}{l}0.05 \mathrm{~mol} \mathrm{dm}^{-3} \\
\text { acetic acid with } \\
\text { ABS; pH } 4.7\end{array}$ & BDDE & +1.10 & MPA & 66.5 & $\begin{array}{l}\text { Pharmaceutical } \\
\text { (tablets) }\end{array}$ & [56] \\
\hline & $\begin{array}{l}0.1 \mathrm{~mol} \mathrm{dm}^{-3} \\
\mathrm{H}_{2} \mathrm{SO}_{4}\end{array}$ & BDDE & +1.25 & MPA & 40.8 & $\begin{array}{l}\text { Pharmaceutical } \\
\text { (oral solution) }\end{array}$ & {$[57]$} \\
\hline Acetylcysteine & $\begin{array}{l}1.0 \mathrm{~mol} \mathrm{dm}^{-3} \\
\mathrm{KOH}\end{array}$ & NiPb-FTOE & +0.40 & Amperometry & 37.5 & $\begin{array}{l}\text { Pharmaceutical } \\
\text { (injectable solu- } \\
\text { tion) }\end{array}$ & {$[58]$} \\
\hline $\begin{array}{l}\text { Acetylsalicylic } \\
\text { acid }\end{array}$ & $\begin{array}{l}0.1 \mathrm{~mol} \mathrm{dm}^{-3} \\
\mathrm{H}_{2} \mathrm{SO}_{4}\end{array}$ & BDDE & +1.30 & MPA & 164.0 & $\begin{array}{l}\text { Pharmaceutical } \\
\text { (tablets) }\end{array}$ & [59] \\
\hline Amiloride & BBS pH 10.0 & BDDE & +0.85 & MPA & 130.0 & $\begin{array}{l}\text { Pharmaceutical } \\
\text { (capsules) }\end{array}$ & {$[60]$} \\
\hline Aminophylline & PBS pH 7.0 & SPCE & +0.90 & MPA & 12.6 & $\begin{array}{l}\text { Pharmaceutical } \\
\text { (tablets, capsules) }\end{array}$ & {$[61]$} \\
\hline Amlodipine & BRBS pH 2.0 & BDDE & +1.00 & Amperometry & 30.3 & $\begin{array}{l}\text { Pharmaceutical } \\
\text { (tablets) }\end{array}$ & {$[62]$} \\
\hline Ampicillin & BRBS pH 7.0 & $\mathrm{CuE}$ & +0.025 & Amperometry & 2500 & $\begin{array}{l}\text { Pharmaceutical } \\
\text { (tablets) }\end{array}$ & {$[63]$} \\
\hline Astaxanthin & $\begin{array}{l}\text { Acetone, dichlo- } \\
\text { romethane, } \\
\text { water }(80: 10: 10 \text {, } \\
v / v / v) \text { con- } \\
\text { taining } \\
0.1 \mathrm{~mol} \mathrm{dm}^{-3} \\
\mathrm{HClO}_{4}\end{array}$ & GCE & +0.80 & Amperometry & 179.1 & $\begin{array}{l}\text { Environmental } \\
\text { (salmon) }\end{array}$ & [33] \\
\hline Atenolol & BRBS pH 2.0 & BDDE & +1.65 & Amperometry & 19.4 & $\begin{array}{l}\text { Pharmaceutical } \\
\text { (tablets) }\end{array}$ & {$[62]$} \\
\hline Benzocaine & PBS pH 7.0 & SPCE & +0.90 & Amperometry & 5.0 & $\begin{array}{l}\text { Environmental (fish } \\
\text { fillets) }\end{array}$ & {$[90]$} \\
\hline \multirow[t]{5}{*}{ Caffeine } & $\begin{array}{l}0.05 \mathrm{~mol} \mathrm{dm}^{-3} \\
\text { acetic acid with } \\
\text { ABS; } \mathrm{pH} 4.7\end{array}$ & BDDE & +1.40 & MPA & 95.2 & $\begin{array}{l}\text { Pharmaceutical } \\
\text { (tablets) }\end{array}$ & {$[56]$} \\
\hline & $\begin{array}{l}0.1 \mathrm{~mol} \mathrm{dm}^{-3} \\
\mathrm{H}_{2} \mathrm{SO}_{4}\end{array}$ & BDDE & +1.60 & MPA & 79.6 & $\begin{array}{l}\text { Pharmaceutical } \\
\text { (tablets) }\end{array}$ & [59] \\
\hline & $\begin{array}{l}0.1 \mathrm{~mol} \mathrm{dm}^{-3} \\
\mathrm{H}_{2} \mathrm{SO}_{4}\end{array}$ & BDDE & +1.55 & SWV & 291.3 & $\begin{array}{l}\text { Pharmaceutical } \\
\text { (tablets) }\end{array}$ & [64] \\
\hline & $\begin{array}{l}0.1 \mathrm{~mol} \mathrm{dm}^{-3} \\
\mathrm{H}_{2} \mathrm{SO}_{4}\end{array}$ & BDDE & +1.60 & MPA & 100 & $\begin{array}{l}\text { Pharmaceutical } \\
\text { (tablets) }\end{array}$ & {$[65]$} \\
\hline & PBS pH 6.86 & $\mathrm{IrO}_{\mathrm{x}} / \mathrm{RuO}_{\mathrm{x}}-\mathrm{GCE}$ & +1.25 & Amperometry & - & $\begin{array}{l}\text { Pharmaceutical } \\
\text { (tablets) }\end{array}$ & [66] \\
\hline Captopril & ABS pH 4.7 & BDDE & +1.40 & MPA & 30.4 & $\begin{array}{l}\text { Pharmaceutical } \\
\text { (tablets) }\end{array}$ & {$[67]$} \\
\hline
\end{tabular}


Table 1 (continued)

\begin{tabular}{|c|c|c|c|c|c|c|c|}
\hline Analyte & $\begin{array}{l}\text { Supporting elec- } \\
\text { trolyte }\end{array}$ & Working electrode & $\begin{array}{l}\text { Detection } \\
\text { potential/V }\end{array}$ & Technique & $\mathrm{LOD} / 10^{-6} \mathrm{~g} \mathrm{dm}^{-3}$ & Analyzed sample & References \\
\hline Carbamazepine & PBS pH 7.0 & SPCE & +1.00 & MPA & 99.2 & $\begin{array}{l}\text { Pharmaceutical } \\
\text { (tablets, capsules) }\end{array}$ & {$[61]$} \\
\hline Carbendazim & BRBS pH 4.0 & MWCNTs-SPE & +0.80 & MPA & 11.5 & $\begin{array}{l}\text { Environmental (tap } \\
\text { water) }\end{array}$ & [91] \\
\hline \multirow[t]{2}{*}{ Catechin } & ABS pH 4.5 & SPCE & +0.30 & Amperometry & 6.1 & $\begin{array}{l}\text { Environmental } \\
\text { (plant extract) }\end{array}$ & [92] \\
\hline & ABS pH 4.5 & GCE & +0.40 & MPA & 8.7 & Food (green tea) & {$[50]$} \\
\hline \multirow[t]{9}{*}{ Catechol } & $\begin{array}{l}0.1 \mathrm{~mol} \mathrm{dm}^{-3} \\
\mathrm{HClO}_{4}\end{array}$ & $\begin{array}{l}\text { NF-MWCNTs- } \\
\text { GCE }\end{array}$ & +0.60 & Amperometry & 6.6 & - & [98] \\
\hline & $\begin{array}{l}0.1 \mathrm{~mol} \mathrm{dm}^{-3} \\
\mathrm{HClO}_{4}\end{array}$ & GCE & +0.60 & Amperometry & 68.9 & - & [99] \\
\hline & $\begin{array}{l}0.1 \mathrm{~mol} \mathrm{dm}^{-3} \\
\mathrm{HClO}_{4}\end{array}$ & ErGO-GCE & +0.60 & Amperometry & 3.4 & - & [99] \\
\hline & $\begin{array}{l}0.1 \mathrm{~mol} \mathrm{dm}^{-3} \\
\mathrm{HClO}_{4}\end{array}$ & CrGO-GCE & +0.60 & Amperometry & 1.3 & - & [99] \\
\hline & $\begin{array}{l}0.1 \mathrm{~mol} \mathrm{dm}^{-3} \\
\mathrm{HClO}_{4}\end{array}$ & BDDE & +0.80 & Amperometry & 13.7 & Clinical (serum) & [84] \\
\hline & $\begin{array}{l}0.1 \mathrm{~mol} \mathrm{dm}^{-3} \\
\mathrm{HClO}_{4}\end{array}$ & rGO-BDDE & +0.80 & Amperometry & 6.2 & Clinical (serum) & [84] \\
\hline & $\begin{array}{l}0.1 \mathrm{~mol} \mathrm{dm}^{-3} \\
\mathrm{HClO}_{4}\end{array}$ & MWCNTs-BDDE & +0.80 & Amperometry & 2.3 & Clinical (serum) & [84] \\
\hline & $\begin{array}{l}0.1 \mathrm{~mol} \mathrm{dm}^{-3} \\
\mathrm{HClO}_{4}\end{array}$ & $\begin{array}{l}\text { MWCNTs/rGO- } \\
\text { BDDE }\end{array}$ & +0.80 & Amperometry & 1.3 & Clinical (serum) & [84] \\
\hline & BRBS pH 4.0 & MWCNTs-SPE & +0.50 & MPA & 5.5 & $\begin{array}{l}\text { Environmental (tap } \\
\text { water) }\end{array}$ & [91] \\
\hline $\begin{array}{l}\text { Chlorine mon- } \\
\text { oxide }\end{array}$ & $\begin{array}{l}\text { BRBS pH } \\
6.0 \text { with } \\
0.05 \mathrm{~mol} \mathrm{dm}^{-3} \\
\mathrm{KCl}\end{array}$ & ITOE & 0.00 & Amperometry & 108.1 & $\begin{array}{l}\text { Environmental (tap } \\
\text { water) }\end{array}$ & {$[34]$} \\
\hline Chlorpheniramine & BRBS pH 10.0 & BDDE & +1.10 & MPA & 137.4 & $\begin{array}{l}\text { Pharmaceutical } \\
\text { (tablets) }\end{array}$ & {$[74]$} \\
\hline \multirow[t]{2}{*}{ Ciprofloxacin } & BRBS pH 4.0 & $\begin{array}{l}\text { NF-MWCNTs- } \\
\text { GCE }\end{array}$ & +1.20 & Amperometry & 13.3 & - & [98] \\
\hline & BRBS pH 4.0 & MWCNTs-SPE & +1.00 & Amperometry & 19.9 & $\begin{array}{l}\text { Pharmaceutical } \\
\text { (tablets, injectable } \\
\text { solution) }\end{array}$ & {$[68]$} \\
\hline Clindamycin & PBS pH 7.0 & SPCE & +0.80 & MPA & 21.3 & $\begin{array}{l}\text { Pharmaceutical } \\
\text { (tablets, capsules) }\end{array}$ & [61] \\
\hline Cocaine & $\begin{array}{l}0.1 \mathrm{~mol} \mathrm{dm}^{-3} \\
\mathrm{HClO}_{4}\end{array}$ & BDDE & +2.10 & SWV & 270.0 & Seized sample & [100] \\
\hline Colchicine & PBS pH 7.0 & SPCE & +1.10 & MPA & 39.9 & $\begin{array}{l}\text { Pharmaceutical } \\
\text { (tablets, capsules) }\end{array}$ & {$[61]$} \\
\hline $\mathrm{Cu}$ & $\begin{array}{l}0.1 \mathrm{~mol} \mathrm{dm}^{-3} \\
\mathrm{HCl}\end{array}$ & SPAuE & +0.20 & SWASV & 0.5 & Biodiesel & [101] \\
\hline \multirow[t]{2}{*}{ Diphenhydramine } & $\begin{array}{l}0.05 \mathrm{~mol} \mathrm{dm}^{-3} \\
\text { acetic acid with } \\
\text { ABS; pH } 4.7\end{array}$ & BDDE & +1.70 & MPA & 194.1 & $\begin{array}{l}\text { Pharmaceutical } \\
\text { (tablets) }\end{array}$ & {$[58]$} \\
\hline & $\begin{array}{l}0.1 \mathrm{~mol} \mathrm{dm}^{-3} \\
\mathrm{H}_{2} \mathrm{SO}_{4}\end{array}$ & BDDE & +1.80 & MPA & 46.0 & $\begin{array}{l}\text { Pharmaceutical } \\
\text { (oral solution) }\end{array}$ & [57] \\
\hline
\end{tabular}


Table 1 (continued)

\begin{tabular}{|c|c|c|c|c|c|c|c|}
\hline Analyte & $\begin{array}{l}\text { Supporting elec- } \\
\text { trolyte }\end{array}$ & Working electrode & $\begin{array}{l}\text { Detection } \\
\text { potential/V }\end{array}$ & Technique & $\mathrm{LOD} / 10^{-6} \mathrm{~g} \mathrm{dm}^{-3}$ & Analyzed sample & References \\
\hline \multirow[t]{14}{*}{ Dopamine } & $\begin{array}{l}0.1 \mathrm{~mol} \mathrm{dm}^{-3} \\
\mathrm{HClO}_{4}\end{array}$ & $\begin{array}{l}\text { NF-MWCNTs- } \\
\text { GCE }\end{array}$ & +0.70 & Amperometry & 6.1 & - & [98] \\
\hline & $\begin{array}{l}0.1 \mathrm{~mol} \mathrm{dm}^{-3} \\
\mathrm{HClO}_{4}\end{array}$ & GCE & +0.60 & Amperometry & 50.7 & - & [99] \\
\hline & $\begin{array}{l}0.1 \mathrm{~mol} \mathrm{dm}^{-3} \\
\mathrm{HClO}_{4}\end{array}$ & ErGO-GCE & +0.60 & Amperometry & 5.0 & - & [99] \\
\hline & $\begin{array}{l}0.1 \mathrm{~mol} \mathrm{dm}^{-3} \\
\mathrm{HClO}_{4}\end{array}$ & CrGO-GCE & +0.60 & Amperometry & 8.4 & - & [99] \\
\hline & $\begin{array}{l}0.1 \mathrm{~mol} \mathrm{dm}^{-3} \\
\mathrm{HClO}_{4}\end{array}$ & BDDE & +0.80 & Amperometry & 15.6 & Clinical (serum) & [84] \\
\hline & $\begin{array}{l}0.1 \mathrm{~mol} \mathrm{dm}^{-3} \\
\mathrm{HClO}_{4}\end{array}$ & rGO-BDDE & +0.80 & Amperometry & 13.2 & Clinical (serum) & [84] \\
\hline & $\begin{array}{l}0.1 \mathrm{~mol} \mathrm{dm}^{-3} \\
\mathrm{HClO}_{4}\end{array}$ & MWCNTs-BDDE & +0.80 & Amperometry & 12.1 & Clinical (serum) & [84] \\
\hline & $\begin{array}{l}0.1 \mathrm{~mol} \mathrm{dm}^{-3} \\
\mathrm{HClO}_{4}\end{array}$ & $\begin{array}{l}\text { MWCNTs/rGO- } \\
\text { BDDE }\end{array}$ & +0.80 & Amperometry & 2.5 & Clinical (serum) & [84] \\
\hline & PBS pH 7.0 & GPE & +0.30 & Amperometry & 55.1 & - & [102] \\
\hline & PBS pH 7.0 & EGPE & +0.30 & Amperometry & 41.4 & - & [102] \\
\hline & PBS pH 7.0 & $\mathrm{O}_{2} \mathrm{GPE}$ & +0.30 & Amperometry & 44.4 & - & [102] \\
\hline & PBS pH 7.0 & $\mathrm{CO}_{2} \mathrm{GPE}$ & +0.30 & Amperometry & 29.1 & - & [102] \\
\hline & $0.1 \mathrm{~mol} \mathrm{dm}^{-3} \mathrm{KCl}$ & SnHCF-BDDE & +0.90 & Amperometry & 32.2 & Biological (saliva) & {$[85]$} \\
\hline & $\begin{array}{l}0.1 \mathrm{~mol} \mathrm{dm}^{-3} \\
\mathrm{HClO}_{4}\end{array}$ & $\begin{array}{l}\text { ZnO/MWCNTs- } \\
\text { GCE }\end{array}$ & +0.60 & Amperometry & 21.5 & - & {$[103]$} \\
\hline Epinephrine & PBS pH 7.0 & SSE & +0.50 & Amperometry & 183.2 & $\begin{array}{l}\text { Pharmaceutical } \\
\text { (injectable solu- } \\
\text { tion) }\end{array}$ & [69] \\
\hline \multirow[t]{2}{*}{ Fipronil } & $\begin{array}{l}0.1 \mathrm{~mol} \mathrm{dm}^{-3} \\
\mathrm{HClO}_{4} / \text { acetone } \\
(50: 50, v / v)\end{array}$ & GCE & +1.60 & Amperometry & 2100 & $\begin{array}{l}\text { Environmental } \\
\quad \text { (insecticide) }\end{array}$ & [93] \\
\hline & $\begin{array}{l}0.1 \mathrm{~mol} \mathrm{dm}^{-3} \\
\mathrm{HClO}_{4} / \text { acetone } \\
(50: 50, v / v)\end{array}$ & MWCNTs-GCE & +1.60 & Amperometry & 1100 & $\begin{array}{l}\text { Environmental } \\
\text { (insecticide) }\end{array}$ & [93] \\
\hline Folic acid & $\begin{array}{l}0.1 \mathrm{~mol} \mathrm{dm}^{-3} \\
\quad \mathrm{NaOH}\end{array}$ & $\begin{array}{l}{\left[\left(\mathrm{Ni}^{\mathrm{II}} \mathrm{TRPyP}\right)-\mu-\right.} \\
\left.\mathrm{O}_{2}\right]_{\mathrm{n}}-\mathrm{GCE}\end{array}$ & +0.50 & Amperometry & 325.3 & $\begin{array}{l}\text { Pharmaceutical } \\
\text { (tablets) }\end{array}$ & [70] \\
\hline \multirow[t]{3}{*}{ Furosemide } & BBS pH 10.0 & BDDE & +1.20 & MPA & 940.0 & $\begin{array}{l}\text { Pharmaceutical } \\
\text { (capsules) }\end{array}$ & {$[60]$} \\
\hline & BRBS pH 4.0 & BDDE & +1.30 & MPA & 215.0 & $\begin{array}{l}\text { Pharmaceutical } \\
\text { (tablets) biologi- } \\
\text { cal (urine) }\end{array}$ & [71] \\
\hline & ABS pH 5.2 & CrGO-GCE & +1.00 & amperometry & 231.5 & $\begin{array}{l}\text { Environmental } \\
\text { (natural water) }\end{array}$ & [94] \\
\hline Gentamicin sulfate & ABS pH 4.4 & BDDE & +2.00 & Amperometry & 339.1 & $\begin{array}{l}\text { Pharmaceutical } \\
\text { (injectable solu- } \\
\text { tion) }\end{array}$ & [72] \\
\hline Glucose $/ \mathrm{H}_{2} \mathrm{O}_{2}$ & $\begin{array}{l}\text { PBS with } \\
0.1 \mathrm{~mol} \mathrm{dm}^{-3} \\
\mathrm{KCl} \mathrm{pH}=6.0\end{array}$ & $\mathrm{CE}$ & -0.25 & Amperometry & 19,800 & $\begin{array}{l}\text { Clinical (artificial } \\
\text { serum) }\end{array}$ & [86] \\
\hline $\mathrm{H}_{2} \mathrm{O}_{2}$ & BRBS pH 4.0 & ITOE & -0.05 & Amperometry & 295.9 & $\begin{array}{l}\text { Environmental (tap } \\
\text { water) }\end{array}$ & [34] \\
\hline
\end{tabular}


Table 1 (continued)

\begin{tabular}{|c|c|c|c|c|c|c|c|}
\hline Analyte & $\begin{array}{l}\text { Supporting elec- } \\
\text { trolyte }\end{array}$ & Working electrode & $\begin{array}{l}\text { Detection } \\
\text { potential/V }\end{array}$ & Technique & $\mathrm{LOD} / 10^{-6} \mathrm{~g} \mathrm{dm}^{-3}$ & Analyzed sample & References \\
\hline $\mathrm{Hg}$ & $\begin{array}{l}0.1 \mathrm{~mol} \mathrm{dm}^{-3} \\
\mathrm{HCl}\end{array}$ & SPAuE & +0.40 & SWASV & 0.7 & Biodiesel & [101] \\
\hline Hydralazine & $1 \mathrm{~mol} \mathrm{dm}^{-3} \mathrm{KOH}$ & NiPt-FTOE & +0.45 & Amperometry & 949.8 & $\begin{array}{l}\text { Pharmaceutical } \\
\text { (tablets) }\end{array}$ & [73] \\
\hline \multirow[t]{2}{*}{$\begin{array}{l}\text { Hydrochlorothi- } \\
\text { azide }\end{array}$} & ABS pH 4.7 & BDDE & +1.80 & MPA & 80.4 & $\begin{array}{l}\text { Pharmaceutical } \\
\text { (tablets) }\end{array}$ & [67] \\
\hline & BRBS pH 4.0 & BDDE & +1.10 & MPA & 187.6 & $\begin{array}{l}\text { Pharmaceutical } \\
\text { (tablets) biologi- } \\
\text { cal (urine) }\end{array}$ & [71] \\
\hline \multirow[t]{6}{*}{ Hydroquinone } & $\begin{array}{l}0.1 \mathrm{~mol} \mathrm{dm}^{-3} \\
\mathrm{HClO}_{4}\end{array}$ & $\begin{array}{l}\text { NF-MWCNTs- } \\
\text { GCE }\end{array}$ & +0.70 & Amperometry & 5.5 & - & [98] \\
\hline & $\begin{array}{l}0.1 \mathrm{~mol} \mathrm{dm}^{-3} \\
\mathrm{HClO}_{4}\end{array}$ & GCE & +0.50 & Amperometry & 17.4 & - & [99] \\
\hline & $\begin{array}{l}0.1 \mathrm{~mol} \mathrm{dm}^{-3} \\
\mathrm{HClO}_{4}\end{array}$ & ErGO-GCE & +0.50 & Amperometry & 6.3 & - & [99] \\
\hline & $\begin{array}{l}0.1 \mathrm{~mol} \mathrm{dm}^{-3} \\
\mathrm{HClO}_{4}\end{array}$ & CrGO-GCE & +0.50 & Amperometry & 5.7 & - & [99] \\
\hline & BRBS pH 4.0 & MWCNTs-SPE & +0.30 & MPA & 2.2 & $\begin{array}{l}\text { Environmental (tap } \\
\text { water) }\end{array}$ & [91] \\
\hline & $\begin{array}{l}0.1 \mathrm{~mol} \mathrm{dm}^{-3} \\
\mathrm{HClO}_{4}\end{array}$ & $\begin{array}{l}\text { ZnO/MWCNTs- } \\
\text { GCE }\end{array}$ & +0.60 & Amperometry & 1.1 & - & [103] \\
\hline Levamisole & BRBS pH 8.0 & SPCE & +1.20 & Amperometry & 28.6 & $\begin{array}{l}\text { Pharmaceutical } \\
\text { (tablets) }\end{array}$ & [75] \\
\hline Levofloxacin & BRBS pH 5.0 & BDDE & +1.30 & Amperometry & 36.1 & $\begin{array}{l}\text { Environmental (tap } \\
\text { water, lake water) }\end{array}$ & [95] \\
\hline Minoxidil & PBS pH 7.0 & SPCE & +0.90 & MPA & 29.3 & $\begin{array}{l}\text { Pharmaceutical } \\
\text { (tablets, capsules) }\end{array}$ & {$[61]$} \\
\hline \multirow[t]{2}{*}{ Naphazoline } & BRBS pH 10.0 & BDDE & +1.30 & MPA & 21.0 & $\begin{array}{l}\text { Pharmaceutical } \\
\text { (tablets) }\end{array}$ & [74] \\
\hline & ABS pH 4.7 & BDDE & +1.45 & SWASV & 8.4 & $\begin{array}{l}\text { Pharmaceutical } \\
\text { (solution) }\end{array}$ & [76] \\
\hline $\mathrm{NO}_{2}^{-}$ & BRBS pH 2.0 & MWCNTs-SPCE & +0.70 & MPA & 2.8 & $\begin{array}{l}\text { Biological (urine, } \\
\text { saliva) clinical } \\
\text { (serum, plasma) }\end{array}$ & [87] \\
\hline \multirow[t]{2}{*}{ Omeprazole } & BRBS pH 6.0 & $\begin{array}{l}\text { NF-MWCNTs- } \\
\text { GCE }\end{array}$ & +1.00 & Amperometry & 3.5 & - & [98] \\
\hline & BRBS pH 8.0 & MWCNTs-SPCE & +1.10 & Amperometry & 3.1 & $\begin{array}{l}\text { Pharmaceutical } \\
\text { (tablets) }\end{array}$ & [77] \\
\hline \multirow[t]{3}{*}{ Paracetamol } & $\begin{array}{l}0.1 \mathrm{~mol} \mathrm{dm}^{-3} \\
\mathrm{H}_{2} \mathrm{SO}_{4}\end{array}$ & BDDE & +1.00 & MPA & 240.4 & $\begin{array}{l}\text { Pharmaceutical } \\
\text { (tablets) }\end{array}$ & [59] \\
\hline & $\begin{array}{c}0.1 \mathrm{~mol} \mathrm{dm}^{-3} \\
\mathrm{H}_{2} \mathrm{SO}_{4}\end{array}$ & BDDE & +0.80 & SWV & 302.3 & $\begin{array}{l}\text { pharmaceutical } \\
\text { (tablets) }\end{array}$ & [64] \\
\hline & $\begin{array}{c}0.1 \mathrm{~mol} \mathrm{dm}^{-3} \\
\mathrm{H}_{2} \mathrm{SO}_{4}\end{array}$ & BDDE & +0.90 & MPA & 200 & $\begin{array}{l}\text { Pharmaceutical } \\
\text { (tablets) }\end{array}$ & {$[65]$} \\
\hline $\mathrm{Pb}$ & $\begin{array}{l}0.1 \mathrm{~mol} \mathrm{dm}^{-3} \\
\mathrm{HCl}\end{array}$ & SPAuE & -0.22 & SWASV & 1.0 & Biodiesel & [101] \\
\hline Phenazopyridine & $\begin{array}{l}\text { PBS pH } 7.0 \\
\text { with methanol } \\
(70: 30, v / v)\end{array}$ & BDDE & +0.75 & MPA & 50.0 & $\begin{array}{l}\text { Pharmaceutical } \\
\text { (tablets) }\end{array}$ & [78] \\
\hline Pheniramine & BRBS pH 10.0 & BDDE & +1.10 & MPA & 144.2 & $\begin{array}{l}\text { Pharmaceutical } \\
\text { (eye drop) }\end{array}$ & [74] \\
\hline Picoxystrobin & BRBS pH 2.0 & BDDE & +1.90 & Amperometry & 587.7 & $\begin{array}{l}\text { Food (mineral } \\
\text { water, spiked) }\end{array}$ & [51] \\
\hline Prazosin & PBS pH 7.0 & SPCE & +0.70 & MPA & 19.2 & $\begin{array}{l}\text { Pharmaceutical } \\
\text { (tablets, capsules) }\end{array}$ & [61] \\
\hline
\end{tabular}


Table 1 (continued)

\begin{tabular}{|c|c|c|c|c|c|c|c|}
\hline Analyte & $\begin{array}{l}\text { Supporting elec- } \\
\text { trolyte }\end{array}$ & Working electrode & $\begin{array}{l}\text { Detection } \\
\text { potential/V }\end{array}$ & Technique & $\mathrm{LOD} / 10^{-6} \mathrm{~g} \mathrm{dm}^{-3}$ & Analyzed sample & References \\
\hline Procainamide & PBS pH 7.0 & SPCE & +0.90 & MPA & 6.5 & $\begin{array}{l}\text { Pharmaceutical } \\
\text { (tablets, capsules) }\end{array}$ & {$[61]$} \\
\hline \multirow[t]{2}{*}{ Propyphenazone } & $\begin{array}{l}0.1 \mathrm{~mol} \mathrm{dm}^{-3} \\
\mathrm{H}_{2} \mathrm{SO}_{4}\end{array}$ & BDDE & +1.30 & SWV & 200.4 & $\begin{array}{l}\text { Pharmaceutical } \\
\text { (tablets) }\end{array}$ & {$[64]$} \\
\hline & $\begin{array}{c}0.1 \mathrm{~mol} \mathrm{dm}^{-3} \\
\mathrm{H}_{2} \mathrm{SO}_{4}\end{array}$ & BDDE & +1.20 & MPA & 300 & $\begin{array}{l}\text { Pharmaceutical } \\
\text { (tablets) }\end{array}$ & {$[65]$} \\
\hline Pyridoxine & $\begin{array}{l}0.1 \mathrm{~mol} \mathrm{dm}^{-3} \\
\mathrm{H}_{2} \mathrm{SO}_{4}\end{array}$ & BDDE & +1.60 & MPA & 91.4 & $\begin{array}{l}\text { Pharmaceutical } \\
\text { (oral solution) }\end{array}$ & [57] \\
\hline Pyrogallol & $\begin{array}{l}0.1 \mathrm{~mol} \mathrm{dm}^{-3} \\
\mathrm{HClO}_{4}\end{array}$ & MWCNT-GCE & +0.90 & Amperometry & 1.6 & Biodiesel & [104] \\
\hline \multirow[t]{2}{*}{ Quercetin } & $\begin{array}{l}\text { PBS pH } 6.0 \text { with } \\
\text { ethanol }(80: 20 \text {, } \\
v / v)\end{array}$ & GCE & +0.30 & MPA & 1.2 & $\begin{array}{l}\text { Environmental } \\
\text { (plant extract) }\end{array}$ & [96] \\
\hline & $\begin{array}{l}\text { PBS pH } 6.0 \text { with } \\
\text { ethanol }(80: 20 \text {, } \\
v / v)\end{array}$ & SPCE & +0.20 & Amperometry & 8.2 & $\begin{array}{l}\text { Environmental } \\
\text { (plant extract) }\end{array}$ & [96] \\
\hline Ranitidine & $\begin{array}{l}0.1 \mathrm{~mol} \mathrm{dm}^{-3} \\
\mathrm{NaCl}\end{array}$ & $\begin{array}{l}\mathrm{rGO} / \mathrm{RuOHCF}- \\
\mathrm{GCE}\end{array}$ & +1.10 & Amperometry & 86.2 & $\begin{array}{l}\text { Pharmaceutical } \\
\text { (tablets) }\end{array}$ & [79] \\
\hline Scopolamine & $\begin{array}{l}0.5 \mathrm{~mol} \mathrm{dm}^{-3} \\
\mathrm{H}_{2} \mathrm{SO}_{4}\end{array}$ & BDDE & +1.80 & SWV & 54.6 & Food (beverage) & {$[52]$} \\
\hline Sibutramine & $\begin{array}{l}0.1 \mathrm{~mol} \mathrm{dm}^{-3} \\
\mathrm{H}_{2} \mathrm{SO}_{4}\end{array}$ & BDDE & +1.80 & SWV & 80.0 & $\begin{array}{l}\text { Environmental } \\
\text { (herbals) food } \\
\text { (dietary) supple- } \\
\text { ments) }\end{array}$ & {$[53]$} \\
\hline Sildenafil & BRBS pH 2.0 & SPCE & +1.10 & Amperometry & 24.7 & $\begin{array}{l}\text { Pharmaceutical } \\
\text { (tablets) }\end{array}$ & {$[80]$} \\
\hline $\begin{array}{l}\text { Levothyroxine } \\
\text { sodium }\end{array}$ & $\begin{array}{l}0.05 \mathrm{~mol} \mathrm{dm}^{-3} \\
\mathrm{H}_{2} \mathrm{SO}_{4}(80 \% \\
\text { methanol })\end{array}$ & G-ORSPE & +0.80 & Amperometry & 80.0 & $\begin{array}{l}\text { Pharmaceutical } \\
\text { (tablets) }\end{array}$ & {$[75]$} \\
\hline \multirow[t]{2}{*}{ Sulfamethoxazole } & PBS pH 7.0 & BDDE & +1.20 & MPA & 227.0 & $\begin{array}{l}\text { Pharmaceutical } \\
\text { (tablets) }\end{array}$ & {$[32]$} \\
\hline & $\begin{array}{l}\text { PBS pH } 7.0 \\
\text { with methanol } \\
(70: 30, v / v)\end{array}$ & BDDE & +1.00 & MPA & 150.0 & $\begin{array}{l}\text { Pharmaceutical } \\
\text { (tablets) }\end{array}$ & [78] \\
\hline Tadalafil & $\begin{array}{l}\text { BRBS pH } 4.0 \\
\text { with } 5 \% \text { DMSO }\end{array}$ & BDDE & +1.30 & Amperometry & 389.4 & $\begin{array}{l}\text { Pharmaceutical } \\
\text { (tablets) }\end{array}$ & {$[81]$} \\
\hline \multirow[t]{2}{*}{$\begin{array}{l}\text { tert-Butylhydro- } \\
\text { quinone }\end{array}$} & $\begin{array}{l}0.1 \mathrm{~mol} \mathrm{dm}^{-3} \\
\mathrm{HClO}_{4}\end{array}$ & NF-MWCNT-GCE & +0.50 & Amperometry & 86.4 & - & [98] \\
\hline & $\begin{array}{l}0.1 \mathrm{~mol} \mathrm{dm}^{-3} \\
\mathrm{HClO}_{4}\end{array}$ & $\begin{array}{l}\text { ZnO/MWCNT- } \\
\text { GCE }\end{array}$ & +0.60 & Amperometry & 13.3 & - & [103] \\
\hline Tetracycline & BRBS pH 10.0 & CrGO-GCE & +0.90 & Amperometry & 16.9 & $\begin{array}{l}\text { Pharmaceutical } \\
\text { (tablets) food } \\
\text { (milk) }\end{array}$ & {$[54]$} \\
\hline Theophylline & PBS pH 7.0 & SPCE & +0.90 & MPA & 5.4 & $\begin{array}{l}\text { Pharmaceutical } \\
\text { (tablets, capsules) }\end{array}$ & {$[61]$} \\
\hline Tricaine & PBS pH 7.0 & SPCE & +0.75 & Amperometry & 8.3 & $\begin{array}{l}\text { Environmental (fish } \\
\text { fillets) }\end{array}$ & {$[90]$} \\
\hline Trimethoprim & PBS pH 7.0 & BDDE & +1.00 & MPA & 173.0 & $\begin{array}{l}\text { Pharmaceutical } \\
\text { (tablets) }\end{array}$ & [32] \\
\hline Trimethoprim & $\begin{array}{l}\text { PBS pH } 7.0 \\
\text { with methanol } \\
(70: 30, v / v)\end{array}$ & BDDE & +1.30 & MPA & 200.0 & $\begin{array}{l}\text { Pharmaceutical } \\
\text { (tablets) }\end{array}$ & [78] \\
\hline
\end{tabular}


Table 1 (continued)

\begin{tabular}{|c|c|c|c|c|c|c|c|}
\hline Analyte & $\begin{array}{l}\text { Supporting elec- } \\
\text { trolyte }\end{array}$ & Working electrode & $\begin{array}{l}\text { Detection } \\
\text { potential/V }\end{array}$ & Technique & $\mathrm{LOD} / 10^{-6} \mathrm{~g} \mathrm{dm}^{-3}$ & Analyzed sample & References \\
\hline \multirow[t]{2}{*}{ Uric acid } & BRBS pH 2.0 & MWCNTs-SPCE & +0.45 & MPA & 8.4 & $\begin{array}{l}\text { Biological (urine, } \\
\text { saliva) clinical } \\
\text { (serum, plasma) }\end{array}$ & [87] \\
\hline & $2 \mathrm{~mol} \mathrm{dm}^{-3} \mathrm{KOH}$ & NiZn-FTOE & +0.10 & Amperometry & 3.9 & $\begin{array}{l}\text { Biological (urine, } \\
\text { saliva) }\end{array}$ & [88] \\
\hline Verapamil & PBS pH 7.0 & SPCE & +1.00 & MPA & 9.1 & $\begin{array}{l}\text { Pharmaceutical } \\
\text { (tablets, capsules) }\end{array}$ & {$[61]$} \\
\hline \multirow[t]{2}{*}{ Warfarin } & PBS pH 7.0 & SPCE & +1.00 & MPA & 21.6 & $\begin{array}{l}\text { Pharmaceutical } \\
\text { (tablets, capsules) }\end{array}$ & {$[61]$} \\
\hline & PBS pH 7.0 & BDDE & +1.20 & MPA & 111.0 & $\begin{array}{l}\text { Pharmaceutical } \\
\text { (tablets) }\end{array}$ & {$[82]$} \\
\hline \multirow[t]{2}{*}{$\mathrm{Zn}$} & ABS pH 4.7 & BDDE & -1.00 & SWASV & 8.2 & $\begin{array}{l}\text { Pharmaceutical } \\
\text { (solution) }\end{array}$ & [76] \\
\hline & BRBS pH 7.0 & $\mathrm{AuE}$ & -0.55 & ASV & 5.0 & Bioethanol & [105] \\
\hline
\end{tabular}

Supporting electrolyte: $A B S$ acetate buffer solution, $B B S$ borate-buffered saline, $B R B S$ Britton-Robinson buffer solution, $P B S$ phosphate buffer solution

Working electrode: $\mathrm{AuE}$ gold electrode, $\mathrm{BDDE}$ boron-doped diamond electrode, $\mathrm{CE}$ carbon electrode, $\mathrm{CO}_{2} G P E$ graphite paper electrode pretreated by cold reactive plasma using $\mathrm{CO}_{2}, C o P c-P G E$ pyrolytic graphite electrode modified with cobalt phthalocyanine, $C r G O-G C E$ glassy carbon electrode modified by chemically reduced graphene oxide, $\mathrm{CuE}$ copper electrode, $\mathrm{CuO}-\mathrm{CuE}$ copper electrode coated with $\mathrm{CuO}, E P G E$ electrochemically treated graphite paper electrode, ErGO-GCE glassy carbon electrode modified by electrochemically reduced graphene oxide, $G C E$ glassy carbon electrode, $G-O R S P E$ graphite organic resistant screen-printed electrode, $G P E$ graphite paper electrode, $I r O_{x} / R u O_{x}-G C E$ glassy carbon electrode modified by electrodeposited Ir-Ru oxides, ITOE indium-doped tin oxide electrode, $M W C N T S-B D D E$ boron-doped diamond electrode modified by multi-walled carbon nanotubes, $M W C N T S-G C E$ glassy carbon electrode modified by multi-walled carbon nanotubes, $M W C N T s / r G O-B D D E$ boron-doped diamond electrode modified by multi-walled carbon nanotubes and reduced graphene oxide, $M W C$ $N T S-S P C E$ screen-printed carbon electrode modified by multi-walled carbon nanotubes, $M W C N T S-S P E$ screen-printed electrode modified by multi-walled carbon nanotubes, $N F-M W C N T s-G C E$ carbon electrode modified by non-functionalized multi-walled carbon nanotubes, $N i P b-$ FTOE fluorine-doped tin oxide electrode modified by $\mathrm{Ni}$ and $\mathrm{Pb}$ nanoparticles, $\mathrm{NiPt}-F T O E$ fluorine-doped tin oxide electrode modified by $\mathrm{Ni}$ and Pt nanoparticles, $\left[\left(\mathrm{Ni}^{I I} T R P y P\right)-\mu-\mathrm{O}_{2}\right]_{n}-G C E$ glassy carbon electrode modified by polymer [(NiI TRPyP $\left.)-\mu-\mathrm{O}_{2}\right]_{\mathrm{n}}, \mathrm{NiZn}-F T O E$ fluorine-doped tin oxide electrode modified by $\mathrm{Ni}$ and $\mathrm{Zn}$ nanoparticles, $\mathrm{O}_{2} G P E$ graphite paper electrode pretreated by cold reactive plasma using $\mathrm{O}_{2}, r G O-$ $B D D E$ boron-doped diamond electrode modified by reduced graphene oxide, $r G O / R u O H C F-G C E$ glassy carbon electrode modified by reduced graphene oxide/ruthenium oxide hexacyanoferrate, $S n H C F-B D D E$ boron-doped diamond electrode modified by drop casting with tin hexacyanoferrate, $S P A u E$ screen-printed gold electrode, SPCE screen-printed carbon electrode, SPGE screen-printed graphite electrode, SSE stainlesssteel electrode; $\mathrm{ZnO} / \mathrm{MWCNTS}-G C E$ glassy carbon electrode modified by multi-walled carbon nanotubes and $\mathrm{ZnO}$ nanoparticles

Technique: $A S V$ anodic stripping voltammetry, $M P A$ multiple pulse amperometry, $S W V$ square-wave voltammetry, $S W A S V$ square-wave anodic stripping voltammetry

connection with MPA has been utilized for direct determination of two or three electroactive molecules in pharmaceutical dosages by a single run $[56,57,59,60,71,74,78]$.

Even if the analyzed samples had a simple matrix, in some cases it was not possible to perform direct simultaneous determination of several electroactive substances because the electrode surface was fouled by oxidation products. This problem could not be eliminated by applying a cleaning potential in MPA and a "memory effect" that caused signal drop was still observed, and for this reason the analytes were determined separately [62].

As an example of the determination of organic molecules in pharmaceutical sample by BIA, we could mention the work of Ferrari et al. They developed the first BIA system for electrochemical determination of epinephrine using mass-produced stainless-steel pins as working electrode. The platform was applied to the determination of epinephrine in injectable solution and showed accurate results. The feasibility of constructed BIA system based on pins was demonstrated by eight pin-based working electrodes in the container. The BIA system set-up has been completed with one reference and one auxiliary pin electrode which were shared for all eight pin-based working electrodes in the container. It also demonstrates the versatility of pins for the construction of electroanalytical systems [69].

\section{Analysis of biological samples}

Another type of samples, in which organic molecules have been determined, is biological samples, such as serum, plasma, saliva, and urine [49, 71, 83-88]. Similar to the previous paragraph, only dilution of real samples in supporting electrolyte was necessary before the analysis. To determine amount of the analyzed substances, calibration 
curve or standard addition method was used depending on the working electrode material and the type of sample. For example, in the case of simultaneous determination of the diuretics in synthetic urine on BDD electrode, external calibration curve was used to determine amount of analytes, which significantly reduced the time of entire process of the analysis. Moreover, it also greatly increased the number of samples which could be analyzed by BIA-MPA system in short time period [71]. On the other hand, in the determination of uric acid in human urine and human saliva on fabricated fluorine-doped tin oxide electrode, standard addition method was applied to determine concentration of uric acid. This could be related to the more complex matrix of the saliva and human urine samples when compared to synthetically prepared urine [88].

Another example of utilization of BIA in bioanalysis is a work of Caetano et al., who developed a portable electroanalytical system for rapid simultaneous determination of uric acid and nitrite in human biological fluids. The method is based on BIA with MPA detection on screen-printed electrodes (SPEs) modified with multi-walled carbon nanotubes (MWCNTs). The sufficient selectivity of the proposed method was evaluated (Fig. 7), which demonstrated selective oxidation of individual substances, as shown by the recorded amperometric responses obtained at $0.45 \mathrm{~V}$ and at $0.70 \mathrm{~V}$ vs. pseudoreference $\mathrm{Ag} / \mathrm{AgCl}$ electrode for injections of $1 \times 10^{-5} \mathrm{~mol} \mathrm{dm}^{-3}$ uric acid (UA), $1 \times 10^{-5} \mathrm{~mol} \mathrm{dm}^{-3}$ nitrite (NIT), and $1 \times 10^{-5} \mathrm{~mol} \mathrm{dm}^{-3}$ mixture solution of UA and NIT (concentration of both substances). This method has been validated and the achieved analytical parameters were more favorable when compared to optimized differential pulse voltammetric method. The matrix interferences on the simultaneous determination of UA and NIT in biological

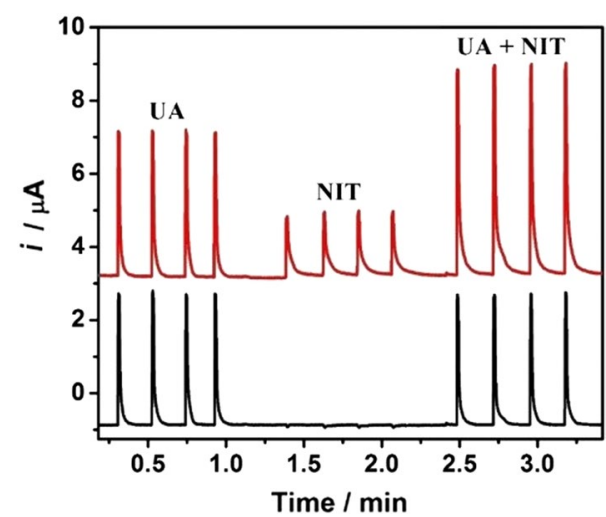

Fig. 7 Amperometric responses $(n=3)$ of solution containing $1 \times 10^{-5} \mathrm{~mol} \mathrm{dm}^{-3} \mathrm{UA}, 1 \times 10^{-5} \mathrm{~mol} \mathrm{dm}^{-3} \mathrm{NIT}$, and $1 \times 10^{-5} \mathrm{~mol} \mathrm{dm}^{-3}$ mixture solution of UA and NIT. Potential pulses: 0.45 and $0.70 \mathrm{~V}$ for $70 \mathrm{~ms}$; supporting electrolyte: $\mathrm{BR}$ buffer $\mathrm{pH}=2.0$; stirring speed of the solution into the BIA cell: $1225 \mathrm{rpm}$; dispensing rate: 277 $\mathrm{mm}^{3} \mathrm{~s}^{-1}$; injection volume: $100 \mathrm{~mm}^{3}$ [87] samples were not observed, probably due to the short contact time of a microliter sample aliquot with the electrode surface [87].

\section{Environmental monitoring}

Environmental monitoring, besides pharmaceutical and foodstuff samples analysis, is also very important area of analytical chemistry, especially from the viewpoint of environmental impact assessments. Several environmental applications of BIA have been developed for the determination of various organic or inorganic substances [32-34, 53, 89-96] in different environmental samples such as lake water, seawater, plant samples, but also fish living in environments. In environmental monitoring unmodified "bare" electrodes were used, but in some cases a working electrode surface was chemically modified which allowed reaching lower LOD of the monitored substances. This is extremely important, especially in the monitoring of trace amounts of dangerous substances in the environment, such as various insecticides and pesticides [93].

As expected, in all cases of determination of organic species in environmental samples, the standard addition method was applied for quantification. It was relevant due to the fact that monitored substances did not occur commonly in nature and it was necessary to confirm usability of developed methods in such complex matrices. Because the analyzed environmental samples had significantly different matrices than the pharmaceutical ones, different extraction pretreatments of the sample (maceration, percolation, and extraction liquid-liquid) was required to be performed in several cases prior to the analysis by BIA system [33, 89, 90, 92, 95].

When samples were not pretreated by extraction, but only diluted in supporting electrolyte, a significant sample matrix effect was noticed, which caused decreasing of registered amperometric signal. This was a consequence of unwanted adsorption process on working electrode during the analysis. Stirring of solution during the analysis was handled to avoid this unacceptable process, which remarkably reduced the value of relative standard deviation, also with regard to the faster washing-out effect of injected complex sample. It caused cutting of the time during which the analyzed sample was in contact with the working electrode surface, which resulted in reduced adsorption of the analyte and its oxidation/reduction products on the electrode. The sample matrix effect on amperometric signal was more significant on MWCNT modified electrode in such a way that after each triplicate injection of analyzed sample, a new modification of the electrode was required [93]. 


\section{Other BIA application}

BIA has been applied for determination of organic molecules in other miscellaneous samples, such as jet fuel, seized sample, and biodiesel [97, 100, 101, 104-106]. In addition, it was also undertaken to monitor electrochemical properties of model organic substances on unmodified or modified electrode surfaces [98, 99, 102, 103].

Despite the fact that analyzed samples had a relatively complex matrix, in most cases only a simple dilution step was required to be carried out prior injection into the BIA cell. The amount of monitored species was determined by external calibration curve or standard addition method, where SWV was used as detection technique.

As a demonstrative example of utilization of BIA in forensic and criminalistic chemistry, a simple and robust method for determination of cocaine and screening of the most common adulterants in seized cocaine sample was developed by Freitas et al. BIA in connection with SWV was employed as a detection technique; however, BIA associated with MPA was also demonstrated for rapid screening of seized cocaine sample. SWV scan has been performed after injection of the sample plug. Electrochemical oxidation of cocaine and adulterants on BDD electrode resulted in a special voltammetric profile. The developed method may be used as an on-site screening method for quick identification of seized cocaine samples [100].

\section{Conclusion and future perspectives}

The proposed review deals with the progress and application of fully automated analytical systems, which may analyze a large number of various samples at high speed. Moreover, they provide precise and accurate results of the analysis without the need to use complicated sample treatment step. BIA has appeared to be potentially optional methods to other automated analytical systems, such as FIA and SIA, because it offers many attractive features for analytical applications involving speed of analysis, simplicity, sample size, sensitivity, reproducibility, cost, and small instrumental device. Another benefit of BIA over FIA is elimination of constantly flowing carrier stream, because the injection of analyzed sample directly against detector is realized by automated micropipette. Over the years, it was also found that BIA no longer needs to handle large detection cells and constantly stirring of analyzed solution, because the analyte or product of its redox reaction is washing out from the working electrode surface by a new injection. Decreasing of cell dimension in BIA has led to significantly reduction of the consumption of used chemicals and analyzed samples, which meets requirements of "Green Analytical Chemistry." Due to miniaturization of instrumental device, the BIA system can be exploited to create portable analytical platforms, where specific attribute of analyzed sample is recorded over appropriate sensors directly for in situ measurements. Currently, many scientists utilize BIA detection cells with precisely defined dimensions manufactured by 3D printing technology in the laboratory, which represents important collaboration of different scientific fields, like Analytical Chemistry, Electrochemistry, and Material Chemistry. The articles published in years from 2015 to 2020 clearly manifest that BDD is considered as the most prospective working electrode material owing to its unique properties. Based on this review, it can be concluded that BIA has great potential to become a routine analytical tool for determination of different organic/ inorganic substances in various matrices, especially in laboratories and situations where experienced operators and sophisticated laboratory equipment are not available.

Acknowledgements This work has been supported by the Grant Agency of the Slovak Republic (VEGA No. 1/0159/20), the STU Grant Scheme for Support of Young Researchers (BIASPE), and the Operational Program Integrated Infrastructure for the project: "Strategic research in the field of SMART monitoring, treatment and preventive protection against coronavirus (SARS-CoV-2)," Project No. 313011ASS8, co-financed by the European Regional Development Fund.

\section{References}

1. Ružička J, Hansen EH (1975) Anal Chim Acta 78:145

2. Squissato AL, Munoz RAA, Banks CE, Richter EM (2020) ChemElectroChem 7:2211

3. Freitas MJ, Oliveira CT, Munoz AAR, Richter ME (2019) Front Chem 7:1

4. Siangproh W, Leesutthipornchai W, Dungchai W, Chailapakul O (2009) J Flow Inject Anal 26:5

5. Gebregewergis A (2021) Am J Sci Res Ess 6:4

6. Wang J, Taha Z (1991) Anal Chem 63:1053

7. Wang J, Rayson GD, Taha Z (1992) Soc App Spec 46:107

8. Bataillard P (1993) Trends Anal Chem 12:387

9. Rahman B, Mahmoud K (2015) Am Chem Sci J 5:214

10. Lu J, Chen Q, Diamond D, Wang J (1993) Analyst 118:1131

11. Diamond D, Lu J, Chen Q, Wang J (1993) Anal Chim Acta 281:629

12. Fernandes JCB, Garcia CAB, Grandin LA, Neto GO, Godinho OSE (1998) J Braz Chem Soc 9:249

13. Lau BBY, Panchompoo J, Aldous L (2015) New J Chem 39:860

14. Silva PW, Oliveira LH, Santos AL, Ferreira VS, Trindade MAG (2018) Food Chem 250:7

15. Andrade SL, Moraes MC, Filho RRC, Filho OF, Cass QB (2009) Anal Chim Acta 654:127

16. Silva AR, Santos JR, Almeida PJ, Rodrigues JA (2021) Food Anal Methods 14:2175

17. Richter EM, Tormin FT, Cunh RR, Silva WP, Junguera AP, Bolado PF, Santos DH, Munoz RAA (2016) Electroanalysis 28:1856

18. Tormin TF, Cunha RR, Silva RAB, Munoz RAA, Richter EM (2014) Sens Actuators B Chem 202:93

19. Rocha DP, Cardoso RM, Tormin TF, Ajauro WR, Munoz RAA, Richter EM, Angnes L (2018) Electroanalysis 30:1386 
20. Ružička J, Marshall DG (1990) Anal Chim Acta 237:329

21. Econoomou A, Tzanavaras PD, Themelis DG (2007) Curr Pharm Anal 3:249

22. Hartwell SK (2012) Int J Hepatol 2012:281807

23. Ružička J, Hansen HE (2008) Trends Analyt Chem 27:390

24. Trojanowicz M (2000) Flow injection analysis: instrumentation and applications. World Scientific Publishing Company, Singapore

25. Capillas CR, Nollet LML (2015) Flow injection analysis of food additives. CRC Press, Florida

26. Yebrabiurrun CM (2009) Flow injection analysis of marine samples. Nova Science Publishers, New York

27. Quintino MMS, Angnes L (2004) Electroanalysis 16:513

28. Brett CAM (2008) Advances in flow analysis. In: Trojanowicz $\mathrm{M}$ (ed) Batch injection analysis. Wiley-VCH Verlag, Weinheim, p 107

29. Wang J, Chen L (1994) Analyst 119:1345

30. Ambrosi A, Pumera M (2016) Chem Soc Rev 45:2740

31. Cardoso RM, Medonca DMH, Silva WP, Silva MNT, Nossol E, Silva RAB, Richter EM, Munoz RAA (2018) Anal Chim Acta 1033:49

32. Pereira FP, Silva WP, Munoz RAA, Richter EM (2015) Quím Nova 38:663

33. Oliveira GFK, Tormin TF, Montes RHO, Richter EM, Munoz RAA (2016) Electroanalysis 28:2143

34. Silva SC, Cardoso RM, Richter EM, Munoz RAA, Nossol E (2020) Mater Chem Phys 250:123011

35. Brett CMA, Brett AMO, Mitoseriu LC (1995) Electroanalysis 7:225

36. Brett CMA, Brett AMO, Mitoseriu LC (1994) Anal Chem $66: 3145$

37. Brett CMA, Brett AMO, Mitoseriu LC (1996) Anal Chim Acta 322:151

38. Wang J, Lu J, Chen L (1992) Anal Chim Acta 259:123

39. Brett CMA, Brett AMO, Matysik FM, Matysik S, Kumbhat S (1996) Talanta 43:2015

40. Brett CMA, Brett AMO, Tugulea L (1996) Electroanalysis 8:639

41. Brett CMA, Morgado JM (2000) J Appl Toxicol 20:477

42. Walcarius A, Lambert L, Derouane E (1995) Electroanalysis 7:120

43. Cardoso LM, Montes RHO, Lima AP, Dornellas RM, Nossol E, Richter EM, Munoz RAA (2015) Electrochim Acta 176:36

44. Svitková V, Labuda J, Vyskočil V (2019) Electroanalysis 31:2001

45. Švorc L, Haššo M, Sarakhman O, Kianíčková K, Stanković DM, Otřísal P (2018) Microchem J 142:297

46. Haššo M, Sarakhman O, Stanković DM, Švorc L (2020) Anal Methods 12:39

47. Sarakhman O, Dubenska L, Švorc L' (2019) J Electroanal Chem $858: 113759$

48. Sarakhman O, Švorc L' (2020). Crit Rev Anal Chem. https://doi. org/10.1080/10408347.2020.1828028

49. Pereira LNS, Silva IS, Araújo TP, Tanaka AA, Angnes L (2016) Talanta 154:249

50. Ribeiro GAC, Rocha CQ, Tanaka AA, Silva IS (2018) Anal Methods 10:2034

51. Dornellas RM, Munoz RAA, Aucelio R (2015) Microchem J 123:1

52. Oliveira TC, Santana MH, Banks CE, Munoz RAA, Richter EM (2019) Electroanalysis 31:567

53. Freitas JM, Oliveira TC, Santana MH, Banks CE, Rodrigo MAA, Richter EM (2019) Sens Actuators B Chem 282:449

54. Faira LV, Lima AP, Araújo FM, Lisboa TP, Matos MAC, Munoz RAA, Matos RC (2019) Anal Methods 11:5328

55. Montes RHO, Lima AP, Santos VB, Vidal TDR, Lago CL, Richter EM, Munoz RAA (2016) Sens Actuators B Chem 231:38
56. Freitas JM, Oliveira TC, Munoz RAA, Richter EM (2017) Quím Nova 40:739

57. Freitas JM, Oliveira TC, Gimenes DT, Munoz RAA, Richter EM (2016) Talanta 146:670

58. Correa AL, Goncalves JM, Rossini PO, Bernandes JS, Neves CA, Araki K, Angnes L (2018) Talanta 186:345

59. Alencar LM, Santos RB, Guedes TJ, Santos WTP, Souza JBG, Ferreira VS, Silva RAB (2018) Electroanalysis 30:296

60. Pereira FP, Silva WP, Marra MC, Munoz RAA, Richter EM (2016) Anal Methods 8:7959

61. Guedes TJ, Santos WTP (2018) Electroanalysis 30:1740

62. Silva AA, Silva LAJ, Munoz RAA, Oliveira AC, Richter EM (2016) Electroanalysis 28:1455

63. Veloso WB, Ribeiro GAC, Rocha CQ, Tanaka AA, Silva IS, Dantas LMF (2020) Measurement 155:107516

64. Silva WP, Silva LAJ, Franca CH, Sousa RMF, Munoz RAA, Richter EM (2017) Electroanalysis 29:1860

65. Silva WP, Silva LAJ, Munoz RAA, Richter EM (2017) Quím Nova 40:1180

66. Shaidarova LG, Chelnokova IA, Degteva MA, Makhmutova GF, Leksina YA, Gedmina AV, Budnikov GK (2016) Pharm Chem J 49:711

67. Gimenes DT, Marra MC, Freitas HM, Munoz RAA, Richter EM (2015) Sens Actuators B Chem 212:411

68. Stefano JS, Cordeiro DS, Marra MC, Richter EM, Munoz RAA (2016) Electroanalysis 28:350

69. Ferrari AGM, Gutiérrez OA, Rama EC, Abedul MTF (2017) Sens Actuators B Chem 253:1207

70. Ferreira LMC, Martins PR, Araki K, Toma HH, Angnes L (2015) Electroanalysis 27:2322

71. Silva EF, Tanaka AA, Fernandes RN, Munoz RAA, Silva IS (2020) Microchem J 157:105027

72. Almeida JMS, Toloza CAT, Machado BS, Silva AR, Aucelio RQ (2019) Microchem J 145:187

73. Azeredo NFB, Rossini PO, Goncalves JM, Assis GL, Araki K, Angnes L (2019) J Taiwan Inst Chem Eng 95:475

74. Oliveira TC, Freitas JM, Munoz RAA, Richter EM (2018) Electroanalysis 30:868

75. Stefano JS, Dias AC, Arantes IVS, Osta BMC, Silva LAJ, Richter EM (2019) Electroanalysis 31:518

76. Oliveira TC, Freitas JM, Munoz RAA, Richter EM (2016) Talanta 152:308

77. Stefano JS, Tormin TF, Silva JP, Richter EM, Munoz RAA (2017) Microchem J 133:398

78. Pereira PF, Silva WP, Munoz RAA, Richter EM (2016) J Electroanal Chem 766:87

79. Borges PHS, Catto AC, Longo E, Nossol E (2020) J Electroanal Chem 878:114558

80. Backes RS, Guedes TJ, Santos WTP, Silva RAB (2017) Quím Nova 40:752

81. Oliveira FM, Ferreira PA, Neves CG, Rosa TM, Santos WTP, Melo EI, Silva RAB (2020) Electroanalysis 32:2253

82. Guedes TJ, Andrade GAR, Lima AB, Silva RAB, Santos WTP (2017) Electroanalysis 29:2340

83. Garcia PT, Dias AA, Souza JAC, Coltro WKT (2018) Anal Chim Acta 1041:50

84. Rocha DP, Silva MNT, Cardoso RM, Castro SVF, Tormin TF, Richter EM, Nossol E, Munoz RAA (2018) Sens Actuators B Chem 269:293

85. Guimaraes GAA, Lacerda JN, Xing Y, Ponzio EA, Pacheco WF, Semaan FS, Dornellas RM (2020) J Solid State Electrochem 24:1769

86. Dias AA, Cardoso TMG, Cardoso RM, Duarte L, Munoz RAA, Richter EM, Coltro WKT (2016) Sens Actuators B Chem 226:196 
87. Caetano LP, Lima AP, Tormin TF, Richter EM, Espindola FS, Botelho FV, Munoz RAA (2018) Electroanalysis 30:1870

88. Azeredo NFB, Goncalves JM, Rossini PO, Araki K, Wang J, Angnes L (2020) Microchim Acta 187:379

89. Oliveira GKF, Tormin TF, Sousa RMF, Oliveira A, Morais SAL, Richter EM, Munoz RAA (2016) Food Chem 192:691

90. Lima RMF, Silva MDO, Felix FS, Angnes A, Santos WTP, Saczk A (2018) Electroanalysis 30:283

91. Caramit RP, Lucca BG, Ferreira VS, Munoz RAA, Richter EM, Silva RAB (2015) Electroanalysis 27:271

92. Ribeiro GAC, Rocha CQ, Veloso WB, Fernandes RN, Silva IS, Tanaka AA (2019) Microchem J 146:1249

93. Montes RHO, Dornellas RM, Silva LA, Squissato AL, Richter EM, Munoz RAA (2016) J Solid State Electrochem 20:2453

94. Vasconcelos SC, Rodrigues EM, Almeida LG, Lepri FG, Pacheco WF, SemaaN FS, Dornelass RM (2020) Anal Bioanal Chem 412:7123

95. Alencar LM, Oliveira LH, Backes R, Rosa TM, Oliveira PR, Silva RAB, Trindale MAG (2017) Electroanalysis 29:2559

96. Ribeiro GAC, Rocha CQ, Veloso WB, Dantas LMF, Richter EM, Silva IS, Tanaka AA (2020) J Solid State Electrochem 24:1759

97. Almeida E, Silva LAJ, Sousa RMF, Richter EM, Foster CW, Banks CE, Munoz RAA (2016) Anal Chim Acta 934:1

98. Stefano JS, Rocha DP, Dornellas RM, Narciso LCD, Krzyzaniak SR, Mello PA, Nossol E, Richter EM, Munoz RAA (2017) Electrochim Acta 240:80
99. Rocha DP, Dornellas RM, Cardoso RM, Narciso LCD, Silva MNT, Nossol E, Richter EM, Munoz RAA (2018) Sens Actuators B Chem 254:701

100. Freitas JM, Ramos DLO, Sousa RMF, Paixao TRLC, Santana MHP, Munoz RAA, Richter EM (2017) Sens Actuators B Chem 243:557

101. Tormin TF, Oliveira GKF, Richter EM, Munoz RAA (2015) Electroanalysis 28:940

102. Pereira JFS, Borges PHS, Moura GM, Gelamo RV, Nossol E, Canobre SC, Richter EM, Munoz RAA (2019) Electrochem Commun 105:106497

103. Freire PG, Montes RHO, Romeiro FC, Lemos S, Lima R, Richter EM, Munoz RAA (2016) Sens Actuators B Chem 223:557

104. Cardoso RM, Dornellas RM, Lima AP, Montes RHO, Richter EM, Munoz RAA (2017) J Braz Chem Soc 28:1650

105. Tormin TF, Narciso LCD, Richter EM, Munoz RAA (2015) Electrochim Acta 164:90

106. Dvořák P, Vyskočil V (2019) Chem Listy 113:703

Publisher's Note Springer Nature remains neutral with regard to jurisdictional claims in published maps and institutional affiliations. 